Article

\title{
Durum Wheat (Triticum durum Desf.): Origin, Cultivation and Potential Expansion in Sub-Saharan Africa
}

\author{
Amadou Tidiane Sall ${ }^{1,2}$, Tiberio Chiari ${ }^{3}$, Wasihun Legesse ${ }^{4}$, Kemal Seid-Ahmed ${ }^{2}$, \\ Rodomiro Ortiz ${ }^{5}$ D, Maarten van Ginkel ${ }^{6}$ and Filippo Maria Bassi ${ }^{2, * \mathbb{D}}$
}

1 Institut Sénégalais de Recherches Agricoles (ISRA), Saint-Louis 46024, Senegal; tidianeassall11@gmail.com

2 International Center for Agricultural Research in the Dry Areas (ICARDA), Rabat 10000, Morocco; s.a.kemal@cgiar.org

3 Italian Agency for Development Cooperation (AICS), Addis Ababa 1000, Ethiopia; tiberio.chiari@aics.gov.it

4 Ethiopian Institute Agricultural Research (EIAR), Agricultural Research Center, Debre Zeit 1000, Ethiopia; wasihunl@yahoo.com

5 Sveriges lantbruksuniversitet (SLU), Institutionen för Växtförädling (VF), 23053 Alnarp, Sweden; rodomiro.ortiz@slu.se

6 International Center for Agricultural Research in the Dry Areas (ICARDA), Amman 1118, Jordan; maartenvanginkel1951@gmail.com

* Correspondence: F.Bassi@cgiar.org; Tel.: +212-614-402-717

Received: 11 April 2019; Accepted: 13 May 2019; Published: 24 May 2019

\begin{abstract}
Durum wheat is an important food crop in the world and an endemic species of sub-Saharan Africa (SSA). In the highlands of Ethiopia and the oases of the Sahara this crop has been cultivated for thousands of years. Today, smallholder farmers still grow it on marginal lands to assure production for their own consumption. However, durum wheat is no longer just a staple crop for food security but has become a major cash crop. In fact, the pasta, burghul and couscous industry currently purchase durum grain at prices 10 to $20 \%$ higher than that of bread wheat. Africa as a whole imports over $€ 4$ billion per year of durum grain to provide the raw material for its food industry. Hence, African farmers could obtain a substantial share of this large market by turning their production to this crop. Here, the achievements of the durum breeding program of Ethiopia are revised to reveal a steep acceleration in variety release and adoption over the last decade. Furthermore, the variety release for Mauritania and Senegal is described to show how modern breeding methods could be used to deliver grain yields above $3 \mathrm{t} \mathrm{ha}^{-1}$ in seasons of just 92 days of length and in daytime temperatures always above $32{ }^{\circ} \mathrm{C}$. This review describes the potential of releasing durum wheat varieties adapted to all growing conditions of SSA, from the oases of the Sahara to the highlands of Ethiopia. This indicates that the new breeding technologies offer great promise for expanding the area of durum wheat production in SSA but that this achievement remains primarily dependent on the market ability to purchase these grains at a higher price to stimulate farmer adoption. The critical importance of connecting all actors along the semolina value chain is presented in the example of Oromia, Ethiopia and that success story is then used to prompt a wider discussion on the potential of durum wheat as a crop for poverty reduction in Africa.
\end{abstract}

Keywords: Agro-industry; Ethiopia; oasis wheat; pasta wheat; Senegal River; value chain

\section{Introduction}

Durum wheat (Triticum durum Desf.) is an important food crop of the world, with an estimated 36 million $t$ of annual global production [1]. The largest producing countries are Turkey and Canada 
with estimated 2 million ha each [2,3], followed by Algeria, Italy and India, each cultivating over 1.5 million ha [4-6]. Syria belonged to this group of large producers but the recent unrest has strongly reduced crop production. France, Greece, Morocco, Pakistan, Portugal, Kazakhstan, Russia, Spain and Tunisia cultivate durum wheat on between 0.5 and 0.8 million ha annually [3]. Azerbaijan, Iraq and Iran combined grow durum wheat on over 0.7 million ha [6]. In addition, Egypt, Jordan and Lebanon grow it on relatively large areas [7-9]. The Sonora desert and other small areas of Mexico also target the production of this crop for the export market on approximately 0.2 million ha [10]. Australia is similarly exploring the cultivation of this crop with 0.1 million ha allocated annually to its production [11]. In sub-Saharan Africa (SSA), Ethiopia is the largest producer of durum wheat, with approximately 0.6 million ha [12].

A very large amount of genetic diversity exists for this crop and that diversity also extends to the many traditional ways of consuming it, including several unique dishes that represent with pride the national identities: pasta, couscous, bourghul, freekeh, gofio and unleavened breads, just to name a few [13]. Regardless of its tight connection to the dishes of the tradition, durum wheat today is cultivated in developed countries mainly as a cash crop to feed the booming food industry. The annual production of pasta was estimated at 14.3 million $t$ in 2013, with a global market approximated at $€ 14.9$ billion and average global price of $1045 € \mathrm{t}^{-1}$ [14]. On a global scale, most of its consumption and production are in Europe, South America and the United States of America. Africa accounts only for $5.6 \%$ of total pasta production, mainly in Egypt, South Africa and Tunisia [14] and Asia consumption is also on the raise. Detailed data for SSA are hard to obtain, as most statistics combine durum wheat with bread wheat into single "wheat" data points but the estimations that could be gathered from several sources suggest an import market of $€ 337$ million and an export market mostly within the continent of $€ 40$ million (Table 1). Reliable data on the size of the internal market were not found. In this review, the developing couscous and bourghul industrial markets are not included, as data are not readily available. Italy, North African, South Africa and Turkey are the largest exporters of pasta to SSA [15]. However, the total area dedicated to durum wheat in SSA is limited to 630,000 ha, of which $90 \%$ is cultivated in Ethiopia. Therefore, this is the only country capable of producing pasta using locally grown grain, while for all other SSA countries the bulk of pasta production required the import of $€ 483$ million worth of durum grain from Canada, Turkey and the USA (Table 1). It must be mentioned that the pasta industry in SSA often utilizes bread wheat flour for its production and typically only products from North Africa and developed countries meet the international standard definition of 'pasta' by using $100 \%$ durum semolina [14]. Clearly, there is huge agricultural and commercial scope for expanding domestic production and marketing of durum wheat in SSA countries.

Durum wheat and rice are the most lucrative among the cereals, with prices usually 20 to $40 \%$ higher than common wheat, millet, maize and sorghum [16]. While durum wheat remains a critical staple food for smallholder farmers in marginal lands, thanks to its exceptional adaptation to climatic stresses, its large-scale production is tightly linked to its greater monetary return. In the absence of governmental subsidies that push toward the cultivation of other crops, farmers tend to prefer durum wheat as long as the market continues to guarantee additional profits. In this regard, the existence of a strong value chain for the pasta, couscous and bourghul industry is quintessential to the success of durum wheat cropping. 
Table 1. Economy and production of durum wheat in Africa and sub-Saharan Africa.

\begin{tabular}{|c|c|c|c|c|c|c|c|}
\hline \multirow{2}{*}{ Country } & \multicolumn{3}{|c|}{ Crop Use per Land } & \multicolumn{2}{|c|}{ Durum Exports ${ }^{b}$} & \multicolumn{2}{|c|}{ Durum Imports ${ }^{b}$} \\
\hline & Rice $^{a}$ & Wheat (all) ${ }^{a}$ & Durum & Grains & Pasta & Grains & Pasta \\
\hline & (ha) & (ha) & (ha) & $(€)$ & $(€)$ & $(€)$ & $(€)$ \\
\hline East & 74,069 & $1,931,714$ & 599,552 & 365,889 & 247,159 & $129,119,247$ & $46,339,452$ \\
\hline Eritrea & - & 25,000 & $12,500^{c}$ & - & - & - & $8,210,000$ \\
\hline Ethiopia & 33,820 & $1,605,654$ & $561,979^{d}$ & & 28,079 & $129,113,334^{n}$ & $24,433,488^{n}$ \\
\hline Kenya & 31,349 & 162,900 & $16,290^{\mathrm{e}}$ & 365,889 & 219,080 & 2177 & $13,695,964$ \\
\hline Somalia & 1338 & 2500 & na & - & - & 3735 & - \\
\hline Sudan & 7562 & 135,660 & $6783^{f}$ & - & - & na & na \\
\hline Central & 206,592 & 44,687 & & & $1,636,218$ & $11,864,150$ & $21,908,766$ \\
\hline Burundi & 21,670 & 8828 & na & - & 1324 & 3136 & 226,183 \\
\hline Cameroon & 166,734 & 660 & na & - & $1,487,086$ & $11,858,665^{\mathrm{n}}$ & $13,442,925^{n}$ \\
\hline Gabon & 620 & - & - & - & 69,532 & 2349 & $5,665,685$ \\
\hline Rwanda & 17,568 & 35,199 & na & - & 78,276 & - & $2,573,974$ \\
\hline South & $1,437,257$ & 608,622 & 26,521 & $38,590,262$ & $11,794,879$ & $148,416,094$ & $86,270,994$ \\
\hline Angola & 29,510 & 3420 & $720 \mathrm{~g}$ & - & - & 1229 & - \\
\hline Madagascar & 909,492 & 2087 & na & - & 2730 & 142,521 & $26,445,917$ \\
\hline Malawi & 65,275 & 1269 & na & - & 3862 & $34,292,325^{n}$ & 808,085 \\
\hline Mozambique & 300,000 & 18,081 & - & 1295 & - & - & $3,568,930$ \\
\hline South Africa & 1150 & 505,500 & $23,456^{\mathrm{h}}$ & $35,183,511$ & $11,702,825$ & $33,889,190$ & $31,108,885$ \\
\hline Uganda ${ }^{1}$ & 93,000 & 14,000 & $100^{\mathrm{i}}$ & 86,843 & 76,540 & $3,673,000$ & $3,935,998$ \\
\hline Zambia & 38,520 & 41,810 & $0^{j}$ & $3,318,613$ & 2177 & - & $5,982,422$ \\
\hline Zimbabwe & 310 & 22,455 & $2246^{\mathrm{k}}$ & - & 6745 & $76,417,829$ & $14,420,757$ \\
\hline West & $7,394,599$ & 102,033 & 4302 & $1,123,513$ & $87,653,612$ & $193,535,341$ & $155,068,054$ \\
\hline Benin & 68,259 & - & & 474,234 & 222,295 & $8,365,599^{n}$ & $50,781,356^{n}$ \\
\hline Burkina Faso & 138,852 & - & - & - & 65,747 & 272,228 & $22,915,826^{n}$ \\
\hline Gambia & 66,380 & - & - & - & 536,030 & - & $5,094,377$ \\
\hline Ghana & 215,905 & - & - & 2340 & $3,633,396$ & 78,376 & $7,847,000^{\circ}$ \\
\hline Guinea & $1,642,687$ & - & - & - & 111,862 & $17,673,754$ & $3,780,845$ \\
\hline Ivory Coast & 791,691 & - & - & 646,939 & $32,545,382$ & $28,513,879^{\circ}$ & $3,024,576^{\circ}$ \\
\hline Mali & 604,745 & 9947 & $1100^{k}$ & - & 211,989 & - & $16,050,025$ \\
\hline Mauritania & 43,900 & 1700 & na $^{1}$ & - & 19,077 & $51,161,839$ & $14,377,271$ \\
\hline Niger & 21,572 & 1883 & na & - & $7,328,976$ & $3,101,758$ & $20,659,562^{n}$ \\
\hline Nigeria & $2,931,400$ & 80,000 & na & - & $40,917,371$ & $38,300,083^{n}$ & $2,633,648$ \\
\hline Senegal & 108,547 & 3 & $2^{\mathrm{m}}$ & - & $2,061,487$ & $46,058,643^{n}$ & $7,903,568$ \\
\hline Sierra Leone & 671,422 & - & - & - & - & 9182 & - \\
\hline Togo & 92,239 & - & - & - & $2,099,984$ & - & $27,284,750^{n}$ \\
\hline sub-Saharan Africa & $9,112,517$ & $2,687,056$ & 632,375 & $40,079,663$ & $101,331,868$ & $482,934,832$ & $309,587,266$ \\
\hline Africa & $9,714,796$ & $9,960,981$ & $3,557,740$ & $40,346,664$ & $215,258,164$ & $4,166,972,506$ & $375,508,531$ \\
\hline
\end{tabular}

${ }^{1}$ The former Sudan is not a true Sub-Saharan country, but it has agro-environmental conditions that differ from North Africa and therefore it is presented here. Data consider Sudan and South Sudan together ${ }^{2}$ Uganda is reported among Southern Africa countries instead of East Africa for its closer similarity in the use of durum wheat a Data obtained from FAOSTAT for the 2013 season [17]. ${ }^{b}$ Data obtained from The Economic Complexity Observatory of the year 2013 [15], except when otherwise indicated. ${ }^{c}$ [18]. ${ }^{\mathrm{d}}$ [19]. ${ }^{\mathrm{e}}$ [20] ${ }^{\mathrm{f}}$ [21]. $\mathrm{g}$ [22]. ${ }^{\mathrm{h}}$ [23]. ${ }^{\mathrm{i}}$ [24]. ${ }^{\mathrm{j}}$ [25]. ${ }^{\mathrm{k}}$ [26]. ${ }^{\mathrm{l}}$ [17]. ${ }^{\mathrm{m}}$ Land surface utilized on-station. ${ }^{\mathrm{n}}$ Data confirmed on Fact-Fish [27]. ${ }^{\circ}$ Data confirmed on Index Mundi [28]. The bold rows indicate sub-totals for different African regions. 
In this review, the current status of durum wheat production in SSA is discussed in comparison to the needs of the local pasta industry to better understand the potential of its expansion through the deployment of novel adapted varieties. Because of its industrial nature, durum wheat has often been disregarded by SSA policy makers in favour of bread wheat as a more direct "food security" approach. However, among the sustainable development goals set by the United Nations, "poverty reduction" is considered as a strategic way to tackle famine, without causing nutritional deficits due to mono-food diets. In this sense, durum wheat is at least as well suited as bread wheat in improving livelihoods. Both aspects of durum wheat, as a "food security" staple food for smallholder farmers, as well as a "poverty reduction" industrial crop will be considered here.

\section{An Endemic Crop of SSA: Durum Wheat Second Centre of Origin in Ethiopia}

Durum wheat originated from the domesticated form of a wild species named emmer wheat (Triticum dicoccum Koern.) between 12,000 and 10,000 years ago, in the West Levantine [29]. Phoenicians have traded it along the Mediterranean shores since historical times and throughout the rise of civilizations this crop has encountered several waves of expansion until today's global importance [30]. However, durum wheat did not originate solely in West Asia. Archaeological evidence suggests that naked emmer reached Ethiopia approximately 5000 years ago [31], probably arriving from the Levantine, through Egypt, along the Silk Road [32]. Today emmer wheat occupies approximately $7 \%$ of the wheat production in Ethiopia under the local name of aja. Recent molecular data [33] indicated that Ethiopian farmers repeated what had been achieved already in West Asia before, by deriving durum wheat anew through the further domestication of emmer. This new origin of the same crop gave rise to a subspecies known as T. turgidum ssp. aethiopicum or abyssinicum. Until relatively recently, landraces belonging to this subspecies were widely cultivated by smallholder farmers in Ethiopia, with up to $80 \%$ of the total durum land farmed with these unique biotypes [34]. The highlands of Ethiopia are known areas of rich biodiversity and durum wheat is no exception [35,36]. For instance, one of the unique characteristics identified among T. aethiopicum landraces is the purple colour of the grains, particularly rich in anthocyanins [37]. Anthocyanins act as anti-oxidants and provide other health benefits, hence these could be potentially exploited by the pasta industry to develop extra nutritious food products. Morphological and molecular characterization of these landraces has only just begun and already several traits such as resistance to diseases (e.g., stem rust, powdery mildew), drought tolerance, long coleoptile, high tillering and resistance sources to Hessian fly have been identified $[38,39]$. This biodiversity has already started attracting strong interest by the international community for utilization, pushing the Ethiopian Government to protect it under strict germplasm exchange policy [18]. In order to conserve these resources, the Ethiopian Biodiversity Institute (EBI) has established a holding of over 7000 accessions collected from different parts of Ethiopia [34]. These collections have been extensively investigated for their morphological and molecular diversity by many researchers and useful traits were identified and are now utilized by breeders and plant genetic conservationists in Ethiopia and beyond [40-48]. In the past two decades, the acreage of traditional tetraploid wheat has drastically diminished due to displacement by improved bread wheat varieties, extensive cultivation of Tef and Kabuli chickpea, farmland fragmentation, policies favouring bread wheat and the absence of a strong seed supply system [49]. To reduce this genetic erosion, EBI has established in situ conservation sites to conserve the agro-biodiversity at the farm level in different parts of Ethiopia. Community biodiversity practices were established in East Shoa and South Wollo zones with the aim of establishing community seed banks, participatory variety selection and the re-introduction of local durum wheat biotypes, food legumes and sorghum into the cropping system $[50,51]$. Regardless of their specific uses, these landraces represent a treasure chest of potentially new and useful traits that breeders could be able to exploit to deliver superior varieties with added market values. 


\section{Durum Wheat in East Africa as a Staple and Cash Crop}

East African countries cultivate almost 2 million ha of wheat, of which only 630,000 ha are farmed with durum wheat (Table 2). Eritrea, Kenya, Somalia and Sudan combined harvested as little as 37,000 ha of durum wheat in 2014. Yet, these countries have maintained in their culinary taste the influence of the past Italian presence in the region, with pasta imports reaching 40 million USD in 2017 in Ethiopia only. In the case of Kenya, national production is sufficient to support the export of $€ 0.5$ million worth of pasta and durum grains.

Table 2. Durum wheat varieties currently cultivated in Sub-Saharan Africa.

\begin{tabular}{|c|c|c|c|c|}
\hline Country & Variety Name & Adoption & Pedigree & Origin \\
\hline Ethiopia & 'Cocorit71' & Old variety, still cultivated & $\begin{array}{l}\text { Enano/4*Tehuacan60// } \\
\text { Stewart63/3/Anhinga }\end{array}$ & CIMMYT \\
\hline Ethiopia & 'Langdon(LD)357' & Old variety, still cultivated & LD308/Nugget & USA \\
\hline Ethiopia & 'Gerardo' & Old variety, still cultivated & $\begin{array}{c}\text { GerardoVZ466/3/ } \\
\text { ND61130/Leeds//Grulla }\end{array}$ & CIMMYT \\
\hline Ethiopia & ‘Ejersa' & $\begin{array}{c}\text { Variety utilized by farmers in } \\
\text { Oromia }\end{array}$ & Labud/Nigris3// Gan & CIMMYT \\
\hline Ethiopia & 'Bakalcha' & $\begin{array}{l}\text { Widely cultivated variety, now } \\
\text { replaced due to susceptibility to } \\
\text { stem rust }\end{array}$ & Gedirfa/Gwerou15 & CIMMYT \\
\hline Ethiopia & 'Ude' & $\begin{array}{l}\text { Variety that replaced Bakalcha in } \\
\text { most zones }\end{array}$ & Chen/Altar// Jori69 & CIMMYT \\
\hline Ethiopia & 'Mangudo' & Covers several districts in Oromia & $\begin{array}{l}\text { Omruf1/Stojocri2/3/1718/ } \\
\text { BeadWheat24//Karim }\end{array}$ & ICARDA \\
\hline Ethiopia & 'Asasa' & Low moisture area in Rift Valley & $\begin{array}{c}\text { Cho/Taurus//Yav/3/Fg/4/ } \\
\text { Cra/5/Fg/Dom/6/Hui }\end{array}$ & national \\
\hline Ethiopia & 'Utuba' & $\begin{array}{l}\text { New favorite by farmers, } \\
\text { cultivated already on } 10,000 \text { ha }\end{array}$ & $\begin{array}{l}\text { Omruf1/Stojocri2/3/ } \\
\text { 1718/BeadWheat24//Karim }\end{array}$ & ICARDA \\
\hline Ethiopia & 'Sinana1' & 18,000 ha & $\begin{array}{c}\text { Emmer selection from } \\
\text { landraces }\end{array}$ & national \\
\hline Ethiopia & 'Lemesso' & 18,000 ha & $\begin{array}{l}\text { Emmer selection from } \\
\text { landraces }\end{array}$ & national \\
\hline Mauritania & ‘Karim' & $\begin{array}{l}\text { Cultivated by farmers along the } \\
\text { Senegal river and in oasis }\end{array}$ & Jori/Anhinga//Flamingo & CIMMYT \\
\hline $\begin{array}{l}\text { Mauritania, } \\
\text { Senegal }\end{array}$ & ‘Haby' & $\begin{array}{l}\text { New release under fats-track } \\
\text { multiplication }\end{array}$ & $\begin{array}{l}\text { Mrb5/T.dico Aleppo } \\
\text { Col//Cham1 }\end{array}$ & ICARDA \\
\hline $\begin{array}{l}\text { Mauritania, } \\
\text { Senegal }\end{array}$ & 'Elwaha' & $\begin{array}{l}\text { New release under fats-track } \\
\text { multiplication }\end{array}$ & $\begin{array}{l}\text { Oslks/5/Azn/4/BezHF/3/ } \\
\text { SD19539//Cham1/Gdr2 }\end{array}$ & ICARDA \\
\hline $\begin{array}{l}\text { Mauritania, } \\
\text { Senegal }\end{array}$ & ‘Bani Suef 5’ & $\begin{array}{l}\text { New release under fats-track } \\
\text { multiplication }\end{array}$ & Dipperz/Bushen3 & CIMMYT \\
\hline Senegal & 'Amina' & $\begin{array}{c}\text { New release under fats-track } \\
\text { multiplication }\end{array}$ & $\begin{array}{l}\text { Korifla/AegSpeltoidesSyr// } \\
\text { Loukos }\end{array}$ & ICARDA \\
\hline Mali & ‘Biskri-Bouteille’ & $\begin{array}{l}\text { Old variety, still cultivated. Only } \\
\text { available recorded release }\end{array}$ & Biskri/Bouteille & national \\
\hline South Africa & ‘Kronos' & Most cultivated variety & APB MSFRS pop selection & USA \\
\hline Kenya & 'Mwewe' & Old variety, still cultivated & Flamingo/Leads & CIMMYT \\
\hline Sudan & 'Sham1' & Old variety, still cultivated & Plc/Ruff// Gta/Rtte & $\begin{array}{l}\text { CIMMYT } \\
\text { ICARDA }\end{array}$ \\
\hline Eritrea & 'Mindum XA10' & Old variety, still cultivated & Mindum/Asmara10 & USA \\
\hline Nigeria & 'Anser8' & Holds potential for adoption & Altar84/Alondra//Sula & CIMMYT \\
\hline
\end{tabular}

The durum varieties used for production are old bred-lines from Centro Internacional de Mejoramiento de Maíz y Trigo (CIMMYT) and International Centre for Agricultural Research in the Dry Areas (ICARDA) such as 'Mwewe' (Flamingo/Leads), Mindum XA10 (Mindum/Asmara 10) and Sham 1 (Plc/Ruff//Gta/Rtte), in Eritrea, Kenya and Sudan, respectively (Table 2). The most critical traits of these varieties are earliness and tolerance to heat in irrigated Sudan and resistance to rust diseases under rainfed cultivation in Eritrea and Kenya. Information from Somalia is scarce and hard to obtain. Considering that the most cultivated durum varieties listed above are more than 30 years old, there is a significant genetic yield gap that could be filled through the release and commercialization of more modern varieties. 
The Ethiopian case is presented in some detail, including critical historical steps, as it provides valuable lessons for other SSA countries planning to grow their durum wheat sector. In Ethiopia, durum wheat is produced predominantly in the Gojam, Gonder, Shewa, Tigrai and Wollo regions [52]. The main growers are smallholder farmers in the highlands, where the environmental characteristics are relatively low temperatures and high rainfall on black swelling/shrinking vertisol soils, with water logging as a common problem. The crop is planted late in the growing season to avoid early water logging and it continues to grow during the dry period on residual moisture at altitudes between 1800 and 2800 m.a.s.l. [44]. Due to late planting, it forfeits some of its additional potential yield in favour of higher protein content. The crop is consumed in several different forms such as unleavened breads, pancakes, macaroni, spaghetti, biscuits and pastries. The most common of the Ethiopian and Eritrean recipes include dabo (Ethiopian home-made bread), hambasha (bread from northern Ethiopia), kitta (unleavened bread), injera (thin bread normally made with Tef), nifro (boiled whole grains), kolo (roasted whole grains), dabo kolo (round and seasoned dough) and kinche (crushed kernels, cooked with milk or water and mixed with spiced butter). Besides the role of grain in traditional food and processed products, durum wheat straw is also greatly appreciated for its high palatability for livestock in the mixed farming systems of the highlands of Ethiopia [53]. Ethiopia today cultivates 562,000 ha of durum wheat [12], accounting for the vast majority of the cultivation of this crop in SSA (Table 2). Still, today's value represents just half of the land that was dedicated to durum wheat in 1967 [54] and this reduction continues in favour of more extensive farming of bread wheat [23]. This is the combined result of political will, the introduction of modern bread wheat cultivars that have replaced the traditional durum wheat landraces and the absence until now of vocal local industry demand of high quality pasta made from durum semolina. Ethiopia's push toward bread self-sufficiency has resulted in a monoculture of bread wheat (as well as maize), often cultivated in both the long (meher) and short (belg) rainy seasons, which in turn created a favourable environment of continuous host presence for the spread of damaging rust diseases and for the surge of tenacious weeds $[55,56]$. Tef, the largest cultivated crop in Ethiopia, also contributes to an expansion of monoculture in Ethiopian agriculture.

Durum wheat research in Ethiopia started back in 1949 at the Paradiso Experimental Station near Asmara [57]. Among several local durum landrace collections tested for productivity and stem and leaf rust resistance, four selections (A10, H23, P20 and R18) were developed and released to farmers in Eritrea in 1952. In 1956 and 1957, several crosses were made between local and exotic varieties mainly for the purpose of transferring the stem and leaf rust resistance of A10 and R18 to cv. 'Mindum' from the USA (Table 2). This resulted in two new varieties, which unfortunately had to be rapidly retracted due to susceptibility to new leaf rust races [58]. In the 1980s, the wheat research activities at the Paradiso station were discontinued and durum wheat breeding was transferred to the Debre Zeit Agricultural Research Centre [42]. At the Centre, many cultivars were developed and released, derived from landrace selections, local crosses and introductions from the international durum wheat breeding programs at CIMMYT and ICARDA. For clarity, in this review the word 'cultivar' has been used to define germplasm cultivated on large amounts of land, while the word 'variety' is reserved to define germplasm officially registered in the variety catalogue of one country. The first durum cultivars released from local breeding selections were 'Arendeto' (DZ04-118) and 'Marou' (DZ04-688), obtained by mass selection [59]. These were followed by the varieties 'Cocorit-71', 'LD-357' and 'Gerardo' obtained from the international agricultural research centres. Since 1982, a formal variety release system has been put in place, which also rationalized the previous work into a variety catalogue, which accounts today for 40 durum wheat cultivars (Figure 1). In the last two decades, many federal and regional agricultural research centres have become involved in durum wheat improvement to respond to the demand by 300 local flour and pasta manufacturers as well as the local consumers. This push by the national food industry, combined with a stronger presence in the region of international development agencies involved in breeding against the emerging Ug99 stem rust race threat [60], has resulted in an increase in the release of durum cultivars, with 20 varieties inscribed in the last 10 years [61]. These new varieties are more responsive to chemical inputs, resistant to diseases and can 
reach average yields of $4-5 \mathrm{t} \mathrm{ha}^{-1}$ under rainfed conditions [62]. 'Utuba' was released in 2015 as an alternative variety to 'Mangudo' and 'Mukuye' because of its amber seeds, high protein content and high yield potential. The grain yield performance on research station ranged from 3.4 to $6.5 \mathrm{tha}^{-1}$ and from 2.5 to $4.5 \mathrm{t} \mathrm{ha}^{-1}$ in farmers' fields [63]. 'Utuba' (Omruf1/Stojocri2/3/1718/BeadWheat24//Karim) takes on average 62 days to flower, 108 days to mature and it is also appreciated for its height $(80-90 \mathrm{~cm})$, which ensures good amount of straw for the livestock. A survey conducted by ICARDA has indicated that farmers that abandon the widely-grown durum cultivar 'Ude' (Chen/Altar//Jori69) to grow the recent release 'Utuba' (Table 2), obtain an average yield gain of 32\% and an equivalent monetary return. Regardless of this clear advantage, adoption by farmers remains very low [64], mainly because of the high cost of purchasing quality seeds, scarce access to agriculture micro-credits and a national seed system incapable of reaching the more remote areas [65]. To solve some of these issues, international agricultural research centres and development agencies together with the national agricultural research institutes have launched a project to develop informal "Community Based Seed Enterprises" [66-69]. This informal system promotes farmers' aggregation around the possibility to gain access to improved seeds from their neighbours. Lead farmers are designated and provided free-of-charge with certified seeds of improved varieties. These leaders are then responsible for multiplying the seeds and providing them to their neighbours for a reasonable price agreed among each other, often involving exchange of livestock, land rental or payments after harvest. A significant effort has been made to expand the production of improved durum wheat cultivars to supply raw materials to the food industries. For example, in the 2018-2019 cropping season, the Bale Zone Bureau of Agriculture up-scaled the cultivation area of two durum wheat cultivars (cvs. Utuba and Mangudo) in nine districts covering over 6244 ha. In the north Shoa-Amhara region, the Africa RISING project, in partnership with the North Shoa Zone Bureau of Agriculture, expanded the area under these two cultivars to over 700 ha. This fast adoption pace is due to the national and international effort of promoting the new varieties but also the great farmers appreciation. Further, the recent contractual agreement between Minjar farmers and the ALVIMA pasta processing factory is predicted to provide an additional push to its adoption.

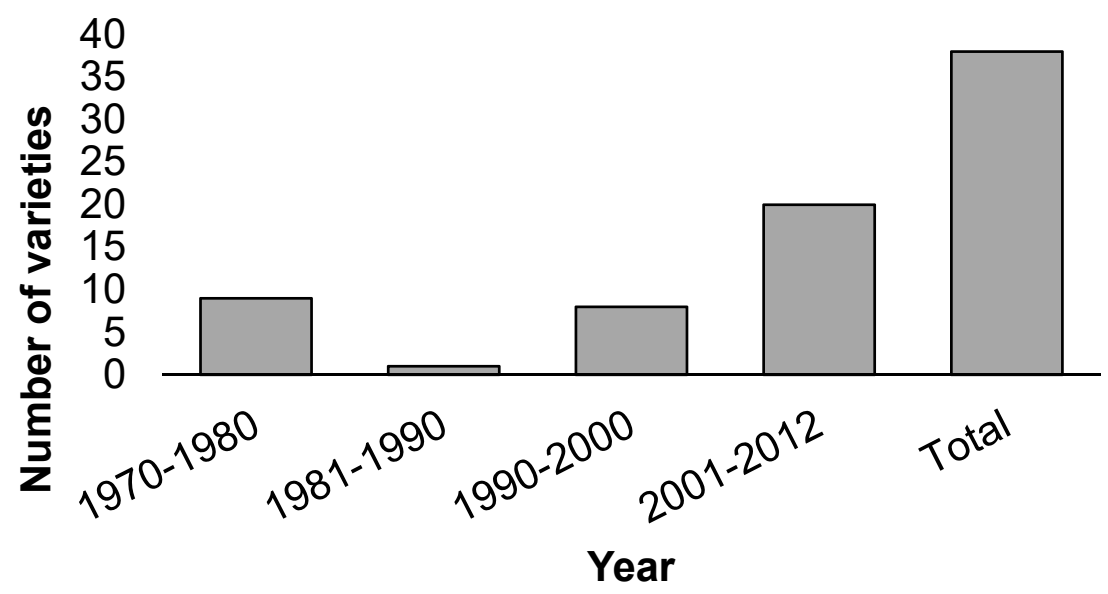

Figure 1. Durum variety releases in Ethiopia since 1970-2012.

Until today, Ethiopia still cultivates emmer wheat, the ancestor of durum wheat. Its cultivation is mainly restricted to marginal areas by about 300,000 households, covering 36,000 ha with an average productivity of $1.7 \mathrm{t} \mathrm{ha}^{-1}$ as recorded during the 2013-2014 season [70,71]. This area also continues to be drastically reduced due to expansion of modern bread wheat cultivars. Improvement of emmer wheat is given little attention and only two cultivars ('Sinana-1' and 'Lemesso') have been released through selection from landraces [61]. This crop is mainly used for the preparation of local food products such as defo or dabo (bread), injera (flat pancake bread), porridge, kita (flat steamed bread), Kinche (boiled coarse grain) and local drinks [72]. Emmer wheat is recommended for mothers as a special diet to maintaining their health and strength after childbirth because of its high protein content 
and digestibility [73]. In fact, its grain protein content ranges from 8.5 to $21.5 \%$, which is $5-35 \%$ higher than in grain from oats or barley and it has a very low glycaemic index [74]. Emmer wheat is also a good source of resistance to leaf and stem rusts, powdery mildew, Septoria glume blotch, Fusarium head blight, Russian Wheat Aphid, in order of importance and tolerance to drought and heat [75-79].

\section{Durum Wheat Value Chain in Oromia Region, Ethiopia}

Recent investments in the pasta industry are proving extremely promising in Ethiopia thanks to new food habits of the growing urban populations, which are looking for fast and tasty foods, while still cheap and nutritious. Pasta has represented a ready-to-use option since its first introduction in Ethiopia in 1938 by the pioneering Italian enterprise Colonalpi (currently called Kaliti Food Share Company), later followed by the establishment of state-owned industries. Today the state industries have been privatized and grouped, together with numerous others, as members of the Ethiopian Millers Association. These pasta producers used to rely on massive importation of durum wheat grains, which was not a sustainable long-term business strategy due to high and volatile costs. Further, the purchase of foreign grains competed with other national priorities for the use of governmental hard currency stocks. Indeed, the revamping of national durum wheat production has caused the reduction of imports to negligible amounts in 2015 [80], after having equalled $€ 129$ million in 2013 (Table 1). However, at the same time, pasta import increased two-fold between 2011 and 2015, when it reached $50,000 \mathrm{t}$ at a cost of about $€ 40$ million [80]. To reverse this trend, the Ethiopian Millers Association has eagerly explored the possibility to procure the needed raw material directly from local farmers to reduce production costs and increase competitiveness against foreign pasta imports. Unfortunately, the local production did not guarantee sufficient rheological grain quality to satisfy the industrial needs. In fact, grain of tetraploid landraces does not meet industrial standards in terms of colour or protein quality, while the high-yielding modern varieties tend to produce bleached and 'chalky' grains when grown on waterlogged vertisols in the absence of abundant nitrogen fertilization [81]. Hence, specific incentives needed to be provided to farmers to obtain industrial-grade harvests. The scope of the Ethiopian-Italian cooperation project for the Agricultural Value Chain in Oromia (AVCPO) was to re-direct some of the already existing bread wheat production system of the Bale zone toward the more lucrative farming of durum wheat for the industry. The process acted on the key elements required by the pasta industry to stabilize and self-sustain the value chain: competitive price, high rheological quality for conversion into pasta, easy and timely delivery, consistent stock of grains and predictable increases over years (Figure 2). Launched in April 2011, the initial steps relied on just two durum varieties (Table 2), identified as highly productive, resistant to prevailing diseases in the Bale zone and with good gluten strength: 'Ejersa' (Labud/Nigris3//Gan) and 'Bakalcha' (980SN Gedirfa/Gwerou15). A total of $40 \mathrm{t}$ of certified seed were purchased from the Sinana Agricultural Research Centre (SARC). The dialogue with the pasta industries resulted in the signing of an innovative supply contract that set the purchase value to the prevailing bread wheat price, with the addition of a 'premium' strictly proportional to kernel protein content. This contract provided the needed incentive to farmers for the application of adequate fertilization strategies and has ensured high grain quality since. Furthermore, to supply the industry with large and uniform stocks of grains, AVCPO promoted farmer aggregation into 15 cooperatives and four unions and provided each with warehouses for temporary storage of grain. To measure the required quality, AVCPO equipped the SARC durum quality laboratory and trained researchers and technicians. Small-holder farmers cultivating around 0.5 to 2.0 ha of land were able to deliver their small sales to the warehouses and from there the industry could purchase large bulked stocks, as needed. Technical assistance to farmers and needed continuous research efforts were delivered by regional research and development institutions both from central and district-commune branches. 


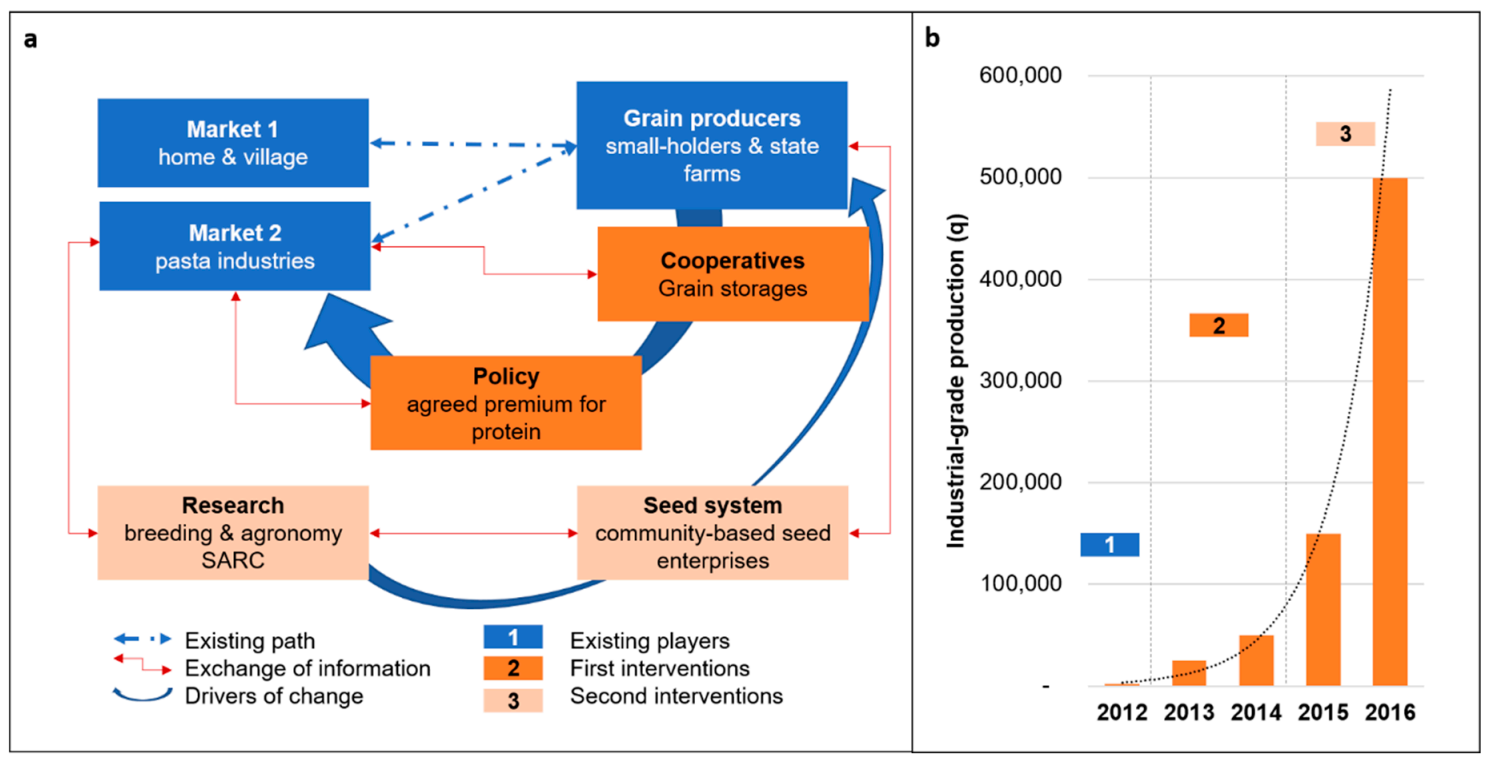

Figure 2. Durum wheat value chain in Oromia, Ethiopia. (a) Schematic of the intervention and value chain key actor relationships: to promote increased income in rural areas, the industrial requirements (market 2) were recorded and used to first promote contractual agreements for the sale of industrial-grade seeds and to assemble the farmers into cooperatives around grain storages and second to drive the research agenda with the release of superior cultivars and their multiplication via community-based seed enterprises; (b) Success indicator measured as the amount of durum grain sold to the food industry from the Oromia region since the inception of the project. SARC refers to the Sinana Agricultural Research Centre.

Highly innovative contractual relationships were created among farmer cooperatives and industries, pushing the surrounding authorities and public institutions to provide support and surveillance on proper accomplishment of duties. Among these, SARC formally acted as neutral third party for measuring the protein content and determining the final price. The emphasis on the highest level of participation and ownership by all involved stakeholders was considered as the key element for the success and sustainability of the development process [82]. Since the first harvest, durum wheat provided to farmers a significant monetary gain per ha of 25 to $30 \%$ over concurrent bread wheat and the industries were greatly satisfied with good rheological quality and reduced prices over imports. The availability of seed stocks of the two selected varieties enabled for prompt expansion of area planted through newly adopting farmers and cooperatives. Over time, the self-sufficient nature of the AVCPO's complex of cooperatives and institutions has created the premises for a vibrant market-oriented community eager to absorb and valorise new varieties and technologies developed by their research partners. Especially in the current situation of evolving rust races dramatically affecting bread wheat in the Bale and other wheat belts, farmers attribute to durum wheat the role of a rescue crop. By the convergence of all these factors, durum wheat production has exponentially increased from $500 \mathrm{t}$ in 2011-2012, to a record harvest of 4.6 million $\mathrm{t}$ in 2017 due mainly to the 'Utuba' recent release and cultivation on large scale. 'Utuba' was christened and released as Ethiopian durum wheat variety in 2015 [83]. In the meantime, the value chain is already expanding to nearby Arsi and Shewa zones. The example of Oromia can be considered a successful approach on integration of the whole durum wheat value chain [84], with a proven rapid and sustainable impact. Hence, it provides a good example to follow for other SSA countries that rely today on durum wheat and pasta imports.

\section{Durum Wheat in West Africa as a Future Cash Crop}

West African countries cultivate over 7 million ha of irrigated rice but only 100,000 ha of wheat (mainly bread wheat) and mostly in Nigeria. A recent steep increase of wheat area has been reported 
for Nigeria but these data are not yet available from FAO statistics, the main source used for compiling Table 1. Still, all West African countries are importers of wheat grain and its derived products. A total of $€ 155$ million worth of pasta and $€ 193$ million worth of durum grains were imported in 2013 (Table 1). Benin is the largest importer of pasta in West Africa with almost $€ 51$ million worth imported in 2013, followed by Niger, Burkina Faso and Togo, which are also among the largest importers in Africa with $€ 20, € 22$ and $€ 27$ million worth, respectively. Interestingly, $€ 87$ million worth of pasta are re-exported each year, mostly by Côte d' Ivoire and Nigeria. Since national durum production is close to zero, it means that large quantities of durum wheat grain are imported internationally, converted by the local industry into pasta products and then sold locally and to neighbouring countries. Hence, as was the case for the Oromia region in Ethiopia, there is potential for national durum cultivation to support this strong local industry, while sharing the $€ 180$ million worth per year of the current import market with the local growers. In Nigeria, initial steps have already been undertaken to identify suitable durum varieties at the Kadawa Kano field station. Here, 12 candidate varieties from CIMMYT's breeding program were assessed over two seasons. Trials revealed that grain yields exceeding $6.2 \mathrm{tha}^{-1}$ could be achieved in 100 days by the top performer 'Anser8' (Altar84/Alondra//Sula) under gravity irrigation [85].

Mauritania is the largest importer of durum grain in West Africa with over $€ 51$ million spent every year. This country has one of the most challenging agro-environments in West Africa, with farming substantially restricted to the narrow band along the Senegal River, where rainfall of up to $600 \mathrm{~mm}$ per year and irrigation water from the river sustain crop production (Agriculture in Mauritania, 2009). The Senegal River basin has a potential of irrigating 135,000 ha [86], of which less than $20 \%$ are currently utilized. The main crops are rice, pearl millet and cowpea. Wheat cultivation along the river is estimated at 8200 ha, of which approximately 5000 ha are grown with durum wheat. The only cultivated durum variety is 'Karim' (syn: 'Yavaros79', Jori/Anhinga//Flamingo), a widely adapted +35 years old CIMMYT-derived variety. Wheat is cultivated during the winter season in rotation with rice and cowpea under gravity irrigation. The window for growing wheat is rather narrow to avoid interfering with the cultivation of the two seasons of rice. Sowing has to occur between the end of November and the middle of December. The harvest is just 80 to 100 days later in early March. Regardless of this short season, two recent projects carried on at the experimental stations of Daara and Kaedi (U-Forsk2013 and SARD-SC) have revealed that yields of $3 \mathrm{t} \mathrm{ha}^{-1}$ could be reached along the Senegal River Valley. In response to these results, three new durum wheat varieties ('Haby' [Mrb5/T.dico Aleppo Col//Cham1], 'Elwaha' [Oslks/5/Azn/4/BezHF/3/SD19539//Cham1/Gdr2] and 'Bezater' [Ossl1/Stj5/5/Bicrederaa1/4/BEZAIZSHF//SD19539/Waha/3/Stj/Mrb3/6/Stj3//Bcr/Lks4/3/Ter3]) were released in 2016 (Table 2) and their seed multiplication has begun [87]. On the opposite shore of the river, the field station of Fanaye in Senegal obtained yields as high as $6 \mathrm{tha}^{-1}$, when early planting towards the end of November was achieved. The irrigable agricultural land of Senegal is divided along three rivers, (in order of importance): Senegal, Faleme and Casamance, thus providing a total estimated irrigable land of 350,000 ha [88]. The Senegal River valley alone accounts for 240,000 ha of potential arable land [89], of which 110,000 ha are currently used for rice cultivation. Since 2017 small-holder farmers started growing improved heat tolerant durum wheat varieties after completion of the rice harvest, during the winter season, which is typically left at fallow. This research achievement, if sustained by polices and market demand, could help replace the $€ 46$ million worth of annual durum import by the national pasta industry. Furthermore, if the total rice area was to be converted to durum wheat instead of the fallow period, then this would be sufficient to generate an overproduction of durum grains to be exported to neighbouring countries for an interesting price. Just as the wheat-rice rotation system has been the cornerstone of India's food self-sufficiency with over 10 million ha still cultivated today [90], it can also become a new boost for the West African agriculture. In addition, the integration of a legume crop in the rotation with durum wheat and rice would be desirable to also increase long-term soil health and agro-ecosystem stability. In this regard, a suggestion is made to replace one rice season with cowpea, an excellent source of food and feed, with very high market 
value. The cropping model suggested would then become rice-durum wheat-cowpea. This expansion into considering a pulse such as cowpea as part of the durum wheat production system is, however, beyond the scope of this review and shall not be discussed further.

A third country relying on the Senegal River for irrigation is Mali, whose production is concentrated along this and the Niger River. The total irrigable land is estimated at 340,000 ha [91] with a potential to further expand. The vast majority of the land is utilized for the production of rice and maize during the warm months. Wheat is cultivated during winter on just $10,000 \mathrm{ha}$, of which a very small portion is durum wheat (Table 1). The old variety 'Biskri-Bouteille' (Biskri/Bouteille) is the only reported release for Mali [92]. It is likely that the breeding activities and import from neighbouring countries have resulted in more modern releases but no document could be located. Similar to its neighbours, Mali imports large quantities of pasta ( $€ 14$ million) and part of it is further exported (€0.2 million). Hence, local production of durum wheat is a viable option for all three countries along the Senegal River. Their total area currently cultivated with rice reaches 754,000 ha. Assuming the same conditions apply to the whole surface, cultivation of durum wheat during the short winter fallow season has the potential to generate additional food, without reducing the current production of their main staple food. The newly identified super-early and heat tolerant durum varieties released in Mauritania and Senegal ('Haby', 'Elwaha', 'Bezater' and 'Amina': Korifla/AegSpeltoidesSyr//Loukos) can provide good industrial grain for the national industry and hold the potential to generate more than 1 million $t$ of additional food in Sub-Saharan Africa [87].

The situation in Nigeria is no different than that observed for the Senegal River countries, even though, with over 80,000 ha farmed to wheat in 2013, it is already the largest bread wheat producer in West Africa (Table 1). A recent push by the Nigerian government, such as the removal of subsidies for the imported grains, has incentivized farmers to increase their wheat production and 2018/19 area harvested and production are estimated at 60,000 hectares and 60,000 tons, respectively [93]. Wheat is typically planted in November or December and harvested around April. The land used for wheat production is then rotated for other rainfed crops during the rainy season, which lasts in northern Nigeria from April to September. Rice is sometimes grown after wheat. The amount of land occupied by durum wheat is not declared in any of the available documents. Certainly, Nigeria imports $€ 38$ million per year of durum wheat grain to be converted into pasta for the national and export market ( $€ 41$ million worth). Hence, the local industry could certainly benefit from an increase in national production. Considering that the area cultivated with rice exceeds 2.9 million ha and that irrigation water is readily available in many parts of the countries, it certainly suggests great potential for expansion.

Similarly, Guinea is a large importer of durum grain (for $€ 17$ million EUR) but none is currently produced on the 1.6 million ha of rice cultivation. Côte d'Ivoire is the largest exporter of pasta ( $€ 32$ million worth per year) but also one of the largest importers of durum grain ( $€ 28$ million worth), with no production of wheat recorded on the 790,000 ha of rice cultivation (Table 1).

In summary, West African countries have the potential to convert their off-season of their 7.2 million ha of rice fields into durum wheat cultivation, instead of having an unproductive winter fallow. New, super-early and heat tolerant varieties have been developed, tested and confirmed along the Senegal River [87] and their seed is readily available through the CGIAR WHEAT program. Their cultivation could turn an annual import market of $€ 185$ million worth of grain and almost $€ 200$ million worth of pasta into a national income to improve industrialization, create jobs and reduce poverty in rural areas.

\section{Southern and Central Africa Durum Wheat Use in the Industry with Limited Cultivation}

Southern and Central African countries cultivate 1.6 million ha of rice and 0.65 million ha of wheat. Unfortunately, data on wheat cultivation in Central Africa are few and unsubstantial. Among Southern African countries, durum wheat is cultivated on just 26,500 ha, mostly in South Africa and Zimbabwe. The most widely cultivated varieties are the 'Desert' durum developed in Arizona and California, with "Kronos" (Arizona Plant Breeders male sterile-facilitated recurrent selection population selection) as 
the preferred one (Table 2). All countries obtain yields above $4 \mathrm{tha}{ }^{-1}$, which only partially meets the national industry demand. Still, part of the grains is exported for generating an income of $€ 38$ million.

All countries combined imported $€ 160$ million worth of durum grain in 2013 (Table 1). The largest importers of grain were Malawi, South Africa and Zimbabwe, which use it to sustain their national pasta industry. In fact, South Africa utilizes the grain to generate pasta for re-export with a value addition of over $€ 11$ million, while Cameroon reaches $€ 1.4$ million of pasta exports annually. Interestingly, some SSA countries do not apply import taxes on durum wheat, which in turn has promoted cases of illegal false labelling of bread wheat grain as durum wheat to avoid custom costs [25]. The import of pasta products in 2013 was $€ 108$ million worth and the biggest importers were South Africa and Madagascar, with $€ 31$ and 26 million worth, respectively. Therefore, a business opportunity exists for the local pasta industry, while creating the chance for growers to improve their livelihoods. Considering an average price per ton of durum wheat grain of $€ 300$ on local markets and attainable yields of 3 ton ha ${ }^{-1}$, approximately 160,000 ha of the currently cultivated 650,000 ha of bread wheat would need to be converted to fill the production gap. Obviously, the reduction of bread wheat would in turn open a gap in the availability of national bread flour, pushing the country to further imports. However, import prices of bread wheat flour is significantly cheaper than durum wheat imports, especially when considering that durum wheat production is a trade that does not require government subsidies to be profitable. Hence, the national economy would overall benefit from a production shift toward durum wheat, as long as this does not upset the higher price paid for semolina. Furthermore, durum-bread wheat flour blends are commonly used in North Africa for the baking of affordable and protein-rich breads.

A second consideration is in regard to the spread of diseases. In fact, South Africa has been monitoring a growing threat of Karnal Bunt disease [94], while Uganda is the first country where the devastating stem rust race Ug99 was observed, before it spread to the neighbouring countries [95]. Both of these diseases affect prevalently bread wheat, while durum wheat has thus far remained resistant $[96,97]$. Hence, replacement of bread wheat by durum wheat would not only have a potential valuable effect on the economy but also reduce the incidence of damaging diseases on the wheat crop. Alternatively, durum wheat could be cultivated on part of the 1.8 million ha dedicated to rice during the fallow off-season period, assuming that adequate rainfall or irrigation water is available. This could be the case for Madagascar, where durum wheat could be cultivated during the off-season in the same terrace fields grown with paddy rice [98]. In fact, a recent study on wheat suitability in SSA [23] using geospatial analysis revealed that Angola, Mozambique, Zambia and Zimbabwe are the countries with the largest potential extension of suitable land for establishing wheat production. The suitable mega environments identified were highlands with high rainfall and frequent diseases (ME2A [99]) and drought prone rainfall with cold winter months (ME4A).

\section{Durum Wheat Cultivation in the Saharan Oases: A Staple Food of Tradition}

The Sahara oases are unique environments that remained impervious to modernization. In this review, both types of oases are considered; those areas of desert where water surfaces from the soil or where it can be collected by human activities through dams (barrage) or other methods as defined by Zaharieva et al. [100]. Semi-nomadic tribes live in these locations and developed self-sustaining agricultural systems based on the sporadic rainfalls and underground or aboveground water accumulations. Several major oases can be found in SSA in Chad, Mali, Mauritania, Niger and Sudan but also in Algeria, Egypt, Libya, Morocco and Tunisia. There are no extensive records of the total area cultivated. The Saharan oases are estimated at a total surface of 900,000 ha, of which approximately half is used for intensive agriculture [100]. Further, average sizes for oases are between 5 and 200 ha of cultivated land, depending on the abundance of yearly rainfall or available percolated water and can sustain the life of up to 1000 people per oasis [101]. In Mauritania, 350 oases account for a total surface of cultivation by wheat (bread and durum) of over 2000 ha [102]. Roughly the same area is cultivated in the oases of Mali [103], while the five largest oases in Algeria (Ghardaia region) account 
for 2200 ha of cereal culture [104] and in Morocco the major oasis region of Errachidia cultivates an approximate 5000 ha of cereals [105]. Cultivated crops include sorghum and millet as rainfed crops, both types of wheat and cowpea as irrigated crops. Larger oases have access to a constant water supply, allowing irrigation by pivot or drip irrigation, such as in the regions of east of Morocco and Algeria [106]. In these cases, water is pumped as needed and wheat is often cultivated among date palms with the moisture used by both cultures. In most other cases, large quantities of water are available only during specific times of the year and to collect it in sufficient amounts for cultivation, it is necessary to build temporary dams with clay, sand and stones. The dam is then opened at the beginning of the winter and as the water recedes, holes are dug into the mud and cereal grains are placed inside (Figure 3). Growing on residual moisture and with high temperatures, the yields rarely exceed $0.5 \mathrm{t} \mathrm{ha}^{-1}$, while under pumped irrigation yields of 4 to $5 \mathrm{t} \mathrm{ha}^{-1}$ are common [107].

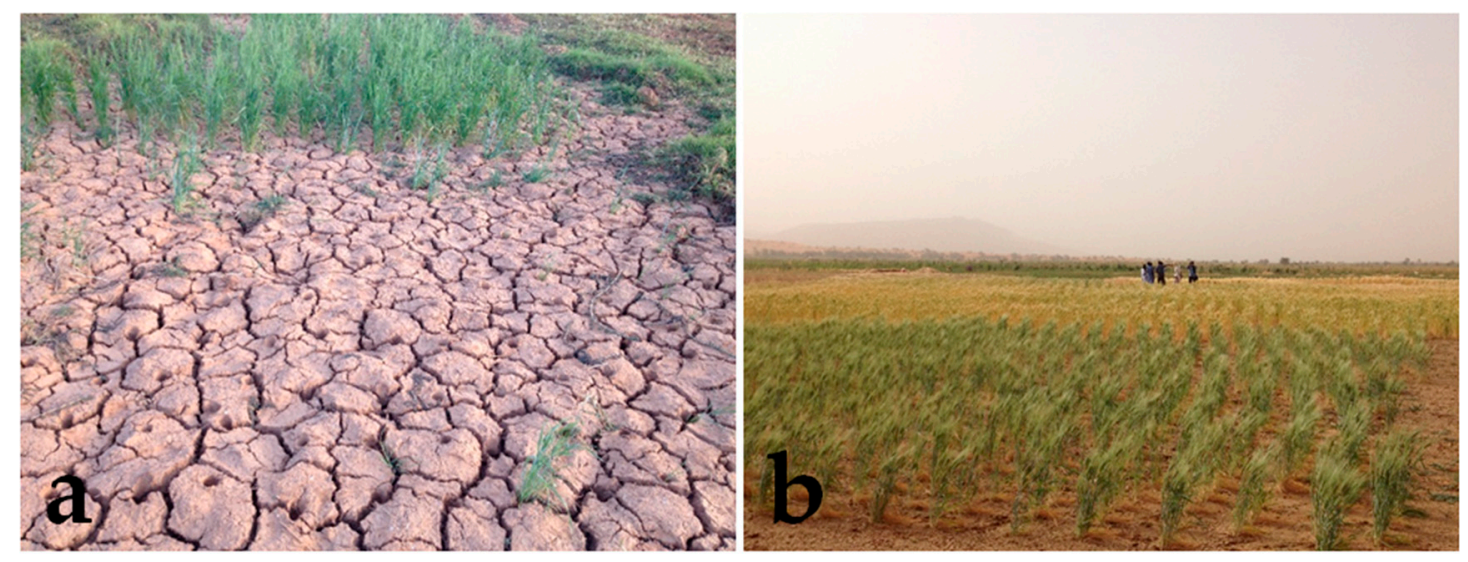

Figure 3. Wheat cultivation in oasis in Mauritania. (a) Holes in the mud for the planting of durum wheat as the water retreats; (b) Gradient on plant maturity caused by the difference in planting time following the retreat of the water.

The farmers of the desert cultivate mostly wheat biotypes of unique morphology defined as oasiensis types, which represent mixtures of several tetraploid and hexaploid wheat species (for review see Reference [108]). Durum wheat cultivation in the oases dates to the initial trade routes between the Nile Valley and West Africa [100]. Several traditional dishes are made from this crop and its straw is very important as feed for the small ruminants and camels. The 'Alkama Binka' is one of the most frequently found landraces in the Saharan oases of Algeria and Morocco [109]. Modern cultivars have also been introduced, such as 'Waha' (syn. 'Cham1', Plc/Ruff//Gta/Rtte) in Algeria and 'Karim' in Mauritania and their superior yields are causing a contraction in the use of landraces (Table 2). The wealth of genetic diversity of germplasm from the Saharan oases has been recognized by several authors and several calls for better collection and conservation have been made but with limited success [108]. In consideration of the harsh environment where these landraces thrive and the fact that durum production will be increasingly stressed due to climate issues [110], they certainly represent a valuable resource of useful alleles for heat, drought and salinity tolerance, which can be deployed in breeding for stress adaptation. Furthermore, the oases represent fragile ecosystems, where land availability is dependent on rainfall and maximum yields per unit of land are more critical than anywhere else. In that sense, the introduction of modern agronomy and irrigation practices, in integration with targeted breeding efforts could deliver true game changers. Alternatively, the reduced available land surface could be used as an advantage to generate very exclusive durum products. In fact, the 'rarity' could be exploited through well integrated value chains to deliver products at elevated prices on the occidental markets, as is already the case for the oases dates. Considering that oases produce less than $5 \%$ of their needs in cereals [104] and the rest is purchased from neighbouring towns, the possibility of generating larger incomes would be a suitable strategy to tackle famine. 
In that sense, the already high value of durum grains could be further exploited via smart-marketing to increase the revenues.

\section{Future Prospects: A South-South Collaboration to Expand Durum Wheat Cultivation in Africa}

All of Africa accounts for an annual import of $€ 4.1$ billion worth of durum grain to supply the national pasta and couscous market. These are mostly imported to North Africa (NA) from Canada, USA and Turkey (Table 1). North Africa already cultivates durum wheat on 2.9 million ha and the area for further expansion is limited. This opens an opportunity for SSA to gain access to an $€ 3.7$ billion annual market by filling part of the grain needs of NA. The current area dedicated to wheat cultivation in SSA is limited to 2.6 million ha, mostly in Ethiopia, South Africa and Sudan. In Ethiopia, new interest has sprung toward the promotion of industrial crops such as durum wheat to provide the local manufacturers with prime raw material without the need of relying on expensive imports. In addition, urbanization has shifted the food habits of many countries and pasta has gained steadily in appreciation by African consumers. Furthermore, the case presented for cultivation of durum wheat in rotation with rice along the Senegal River, matches what is already customary on over 10 million ha of wheat-rice or wheat-rice-rice rotations in India [90]. In that sense, there is large potential for wheat expansion on the 9.1 million ha of rice land in SSA. Since further expansion of the wheat areas will require additional investments and will face the risk of reduced yields, it appears logical to seek the wheat type that would provide the maximum monetary return for unit of land converted. Durum wheat in this case would represent an ideal cash crop to help reduce poverty in SSA. For comparison, the average import prices of major cereals to South Africa [111] for the year 2015 were at: US\$ $502 \mathrm{t}^{-1}$ aromatic rice, US $\$ 330 \mathrm{t}^{-1}$ durum wheat, US\$278 $\mathrm{t}^{-1}$ malt barley, US $\$ 209 \mathrm{t}^{-1}$ hard red bread wheat, US $\$ 171 \mathrm{t}^{-1}$ sorghum and US $\$ 150 \mathrm{t}^{-1}$ feed maize. While it is true that import prices change for each country based on access to trade, existence of infrastructure and specific import policies, South Africa provides a good example of a reactive trading nation in SSA. On this basis, it is evident that durum wheat remains one of the most income advantageous winter cereals, significantly more expensive than bread wheat and malt barley. However, to succeed in the utilization of the financial return of this crop, it is necessary to have a well-integrated value chain capable of delivering profitable economic returns to farmers. The example of the value chain in the Oromia region of Ethiopia could be repeated in several other regions and should provide a good guideline to follow for out-scaling to other countries. Still, the industrial machinery and the strategy for production need to be harmonized among African countries to generate a fair and vibrant market. The desire for semolina-based food is expected to increase in the years to come [112] but the national industry will be successful in targeting the demand only if their products can compete not just in price but also in quality with the imported ones. In that sense, great traditional and modern knowledge for cultivation and production of this crop exist already in North Africa and Ethiopia. Breeding programs for this crop have been successful in targeting the harsh drought conditions of North Africa and the disease pressure in Ethiopia. In order to expand the production of this crop to non-traditional territories, the expertise gathered there could be transferred to SSA in the form of novel and adapted varieties. It is therefore desirable that Ethiopian breeders could produce varieties well adapted to the SSA mega-environment of type 2A, with high rainfall and high disease pressure. Instead, Egyptian breeders could help in delivering varieties targeted to the hot and irrigated areas of mega-environment type ME1, such as West Africa and Sudan. The other North African countries could target ME4A, with low rainfall and cold winters, as well as help in the further development of the Saharan oases. Altogether, this envisioned South-South collaboration could ensure that varieties developed in traditional durum growing areas such as North Africa and Ethiopia, would adapt to the conditions of the southern partners. Harvests could then be sold to those African countries with strong pasta industries and the finished semolina products would be sold all over Africa. This integrated value chain would ensure a steep increase in monetary circulation and an overall reduction in the poverty of Africa. Recent publicly funded projects like Africa Rising [113], 
SARD-SC [114], TAAT [115] and U-Forsk2018 have targeted the increase in production of wheat in SSA and created the basis to hope for a comprehensive "durum wheat revolution" in SSA.

Author Contributions: Writing-original draft preparation, A.T.S., F.M.B., T.C., W.L.; Writing-review and editing, F.M.B., A.T.S., M.v.G., and K.S.; supervision, F.M.B., M.v.G., R.O.; project administration, R.O.; funding acquisition, F.M.B., R.O.

Funding: This research was funded by the Swedish Research Council (Vetenskapsrådet) U-forsk 2013-6500 "Deployment of molecular durum breeding to the Senegal basin: capacity building to face global warming" and U-forsk 2017-05522 "Genomic prediction for breeding durum wheat along the Senegal River Basin".

Conflicts of Interest: The authors declare no conflict of interest. The founding sponsors had no role in the writing of the manuscript and in the decision to publish the results.

\section{References}

1. Chris, G. World Durum Outlook. Available online: http://www.internationalpasta.org/resources/IPO $\%$ 20BOARD\%202013/2\%20Chris\%20Gillen.pdf (accessed on 7 April 2017).

2. Statistic Canada. Canada: Outlook for Principal Field Crops. Available online: http: //www.agr.gc.ca/eng/industry-markets-and-trade/statistics-and-market-information/by-product-sector/ crops-industry/outlook-for-principal-field-crops-in-canada/canada-outlook-for-principal-field-cropsfebruary-16-2016/?id=1455720699951 (accessed on 7 April 2017).

3. USDA Foreign Agricultural Service. Grain and Feed Annual; GAIN Report No: TR5016; USDA Foreign Agricultural Service: Ankara, Turkey, 2015.

4. Nagarajan, S. Quality characteristics of Indian wheat. In Future of Flour; Popper, L., Schäfer, W., Freund, W., Eds.; AgriMedia GmbH: Clenze, Germany, 2006; pp. 79-86.

5. Le Lamer, O.; Rousselin, X. The durum wheat market. In Studies of FranceAgriMer; Bova, F., Ed.; FranceAgriMer: Montreuil-sous-Bois CEDEX, France, 2011; pp. 1-46.

6. Bonjean, A.P.; Angus, W.J.; van Ginkel, M. The World Wheat Book: A History of Wheat Breeding; Lavoisier: Paris, France, 2016; Volume 3.

7. Al-Issa, T.A.; Samarah, N.H. Tillage practices in wheat production under rainfed conditions in Jordan: An economic comparison. World J. Agric. Sci. 2006, 2, 322-325.

8. Karam, F.; Kabalan, R.; Breidi, J.; Rouphael, Y.; Oweis, T. Yield and water-production functions of two durum wheat cultivars grown under different irrigation and nitrogen regimes. Agric. Water Manag. 2009, 96, 603-615. [CrossRef]

9. El-Areed, S.; Nachit, M.M.; Hagaras, A.; El-Sherif, S.; Hamouda, M. Durum wheat breeding for high yield potential in Egypt. In Proceedings of the International Symposium on Genetics and Breeding of Durum Wheat; Porceddu, E., Damania, A.B., Qualset, C.O., Eds.; CIHEAM: Bari, Italy, 2014; pp. 291-294.

10. Juarez, B.; Wolf, D. Grain and feed annual Mexico. In Global Agricultural Information; USDA Foreign Agricultural Service: Washington, DC, USA, 2015; pp. 1-17.

11. John, K. Durum Wheat Production. Available online: http://www.nvtonline.com.au/wp-content/uploads/ 2013/03/Crop-Guide-NSW-Durum-Wheat-Production.pdf (accessed on 24 December 2016).

12. Evan School Policy Analysis and Research (EPAR). Wheat Value Chain: Ethiopia. Available online: https://evans.uw.edu/sites/default/files/EPAR_UW_204_Wheat_Ethiopia_07272012.pdf (accessed on 24 December 2016).

13. Elias, E.M. Durum wheat products. In Durum Wheat Quality in the Mediterranean Region; Di Fonzo, N., Kaan, F., Nachit, M., Eds.; CIHEAM: Zaragoza, Spain, 1995; Volume 22, pp. 23-31.

14. International Pasta Organisation (IPO). The Truth about Pasta Toolkit. Available online: http://www. internationalpasta.org/index.aspx?id=47 (accessed on 27 December 2016).

15. Simoes, A.J.G.; Hidalgo, C.A. The Economic Complexity Observatory: An analytical tool for understanding the dynamics of economic development. In Scalable Integration of Analytics and Visualization; San Francisco, CA, USA, 2011.

16. Food Price Index (FPI). Available online: http://www.fao.org/worldfoodsituation/foodpricesindex/en/ (accessed on 22 December 2016).

17. Food and Agriculture Organization (FAO). FAO Statistical Yearbook 2014: Africa; Tijani, B., Gennari, P., Eds.; FAO: Rome, Italy, 2014. 
18. Food and Agriculture Organization (FAO). Eritrea: Country Report. In Proceedings of the FAO International Technical Conference on Plant Genetics, Leipzig, Germany, 17-23 June 1996.

19. Bill and Melinda Gates Foundation (BMGF). Multi Crop Value Chain Phase II: Wheat Ethiopia. Available online: https://agriknowledge.org/files/8k71nh141 (accessed on 10 January 2017).

20. What Farming in Kenya. Available online: https://informationcradle.com/kenya/wheat-in-kenya/ (accessed on 15 May 2019).

21. Saunders, D.A.; Hettel, G.P. Wheat in Heat-Stressed Environments: Irrigated, Dry Areas and Rice-Wheat Farming Systems; UNDP; ARC; BARI; CIMMYT: Mexico, 1993; ISBN 968-6127-87-9.

22. Mistretta, G. Angola: Alcune caratteristiche del mercato della pasta. Ricadute sul Prodotto Italiano. Ambassador letter on 06 November 2013 to InfoMercatiEsteri.it. Available online: http://www. infomercatiesteri.it/public/images/paesi/4/files/PASTA\%20di\%20grano.doc (accessed on 15 May 2019).

23. Negassa, A.; Shiferaw, B.; Koo, J.; Sonder, K.; Smale, M.; Braun, H.J.; Gbegbelegbe, S.; Guo, Z.; Hodson, D.; Wood, S.; et al. The Potential for Wheat Production in Africa: Analysis of Biophysical Suitability and Economic Profitability; CIMMYT: DF, Mexico, 2013.

24. Ssekitoleko, G.W.; Vogel, W.O. Wheat marketing and pricing policy in Uganda: A critical assessment. In Proceedings of Theninth Regional Wheat Workshop for Eastern, Central and Southern Africa, Addis Abeba, Ethiopia, 2-6 October 1995; Tanner, D.G., Payne, T.S., Abdalla, O.S., Eds.; CIMMYT: Mexico City, Mexico, 1995.

25. United States Agency for International Development (USAID). Staple Foods Value Chain Analysis: Country Report Zambia; Chemonics International Inc.: Washington, DC, USA, 2009.

26. Kayoed-Anglade, S.; Aaron, R. Projet du Moulin Modern du Mali. Available online: https://www.afdb.org/fileadmin/uploads/afdb/Documents/Environmental-and-Social-Assessments/Mali_ -_Projet_du_moulin_moderne_du_Mali_-_R\%c3\%a9sum\%c3\%a9_PGES.pdf (accessed on 4 January 2017).

27. Factfish: Research Made Simple. Available online: www.factfish.com (accessed on 15 May 2019).

28. Index Mundi. Available online: www.indexmundi.com (accessed on 15 May 2019).

29. Hakan, O.; Willcox, G.; Graner, A.; Salamini, F.; Kilian, B. Geographic distribution and domestication of wild emmer wheat (Triticum dicoccoides). Genet. Resour. Crop Evol. 2010, 58, 11-53.

30. Benbelkacem, A.; Khaldounl, A.; Djenadi, C. The history of wheat breeding in Algeria. In World Wheat Book: A History of Wheat Breeding; Bonjean, A.P., Angus, W.J., van Ginkel, M., Eds.; Lavoisier: Paris, France, 2016; Volume 3, pp. 477-495.

31. National Research Council. Lost Crops of Africa: Volume I: Grains; The National Academies Press: Washington, DC, USA, 1996.

32. Luo, M.C.; Yang, Z.L.; You, F.M. The structure of wild and domesticated emmer wheat populations, gene flow between them and the site of emmer domestication. Theor. Appl. Genet. 2007, 114, 947-959. [CrossRef]

33. Kabbaj, H.; Sall, A.T.; Al-Abdallat, A.; Geleta, M.; Amri, A.; Filali-Maltouf, A.; Belkadi, B.; Ortiz, R.; Bassi, F.M. Genetic Diversity within a Global Panel of Durum Wheat (Triticum durum) Landraces and Modern Germplasm Reveals the History of Alleles Exchange. Front. Plant Sci. 2017, 8, 1277. [CrossRef] [PubMed]

34. Mengistu, D.K.; Kirosa, Y.A.Y.; Pè, M.E. Phenotypic diversity in Ethiopian durum wheat (Triticum turgidum var. durum) landraces. Crop J. 2015, 3, 190-199. [CrossRef]

35. Vavilov, N.I. The origin, variation, immunity and breeding of cultivated plants, trans from the Russian by Starr Chester, K., Waltham, Mass.: Chronica Botanica. Science 1951, 115, 364.

36. Pecetti, L.; Annicchiarico, P.; Damania, A.B. Biodiversity in a germplasm collection of durum wheat. Euphytica 1992, 60, 229-238.

37. Ficco, D.B.M.; Mastrangelo, A.M.; Trono, D.; Borrelli, G.M.; De Vita, P.; Fares, C.; Beleggia, R.; Platani, C.; Papa, R. The colors of durum wheat: A review. Crop Pasture Sci. 2014, 65, 1-15. [CrossRef]

38. Mass, F.B.; Paterson, F.L.; Foster, J.E.; Ohm, H.W. Expression and inheritance of resistance of ELS 6404-160 durum wheat to Hessian Fly. Crop Sci. 1989, 29, 23-28. [CrossRef]

39. Belay, G.; Merker, A.; Tesfaye, T. Cytogenetic studies in Ethiopian landraces of tetraploid wheat (Tritium turgidum L.), spike morphology and ploidy level and karyomorphology. Hereditas 1994, 121, 45-52. [CrossRef]

40. Bekele, E. Analysis of regional patterns of phenotypic diversity in the Ethiopian tetraploid and hexaploid wheats. Hereditas 1984, 100, 131-154. [CrossRef]

41. Negassa, M. Estimates of phenotypic diversity and breeding potential of Ethiopian wheats. Hereditas 1986, 104, 41-48. [CrossRef] 
42. Tesemma, T.; Belay, G. Aspects of Ethiopian tetraploid wheats with emphasis on durum wheat genetics and breeding research. In Wheat Research in Ethiopia: A Historical Perspective; Hailu, G., Tanner, D.G., Mengistu, H., Eds.; CIMMYT: El Batan, Mexico, 1991; pp. 47-72.

43. Belay, G.; Tesfaye, T.; Becker, H.C.; Merker, A. Variation and interrelationships of agronomic traits in Ethiopian tetraploid wheat landraces. Euphytica 1993, 71, 181-188. [CrossRef]

44. Bechere, E.; Belay, G.; Mitiku, D.; Merker, A. Phenotypic diversity of tetraploid wheat landraces from northern and north-central regions of Ethiopia. Hereditas 1996, 124, 165-172. [CrossRef]

45. Tsegaye, S.; Tesemma, T.; Belay, G. Relationships among tetraploid wheat (Triticum turgidum L.) landrace populations revealed by isozyme markers and agronomic traits. Theor. Appl. Genet. 1996, 93, 600-605. [CrossRef]

46. Eticha, F.; Bekele, E.; Belay, G.; Börner, A. Phenotypic diversity in tetraploid wheats collected from Bale and Wello regions of Ethiopia. Plant Genet. Resour. 2005, 3, 35-43. [CrossRef]

47. Mengistu, D.K.; Kidane, Y.G.; Catellani, M.; Frascaroli, E.; Fadda, C.; Pe, M.E.; Dell'Acqua, M. High-density molecular characterization and association mapping in Ethiopian durum wheat landraces reveals high diversity and potential for wheat breeding. Plant Biotechnol. J. 2016, 14, 1800-1812. [CrossRef] [PubMed]

48. Mengistu, D.K.; Kidane, Y.G.; Fadda, C.; Pè, M.E. Genetic diversity in Ethiopian Durum Wheat (Triticum turgidum var durum) inferred from phenotypic variations. Plant Genet. Resour. 2016, 16, 39-49. [CrossRef]

49. Tsegaye, B.; Berg, T. Utilization of durum wheat landraces in East Shewa, central Ethiopia: Are home uses an incentive for on-farm conservation? Agric. Hum. Values 2007, 24, 219-230. [CrossRef]

50. Fassil, K.; Sehaye, Y.T.; McNeilly, T. Diversity of durum wheat (Triticum durum Desf.) at in situ conservation sites in North Shewa and Bale, Ethiopia. J. Agric. Sci. 2001, 136, 383-392.

51. Israel, O.K.; Bhandari, B.; Guilherme de Azevedo, S.; Natarajan, K.; Gezu, G.; Gashu, S.; Desalegn, T. Global Study on CBM and Empowerment, Ethiopia Exchange Report; Wageningen University: Wageningen, The Netherlands, 2010; p. 42.

52. Tesemma, T.; Belay, G.; Worede, M. Morphological diversity in tetraploid wheat landrace populations from the central highlands of Ethiopia. Hereditas 1991, 114, 171-176.

53. Tolera, A.; Tsegaye, B.; Berg, T. Effects of variety, cropping year, location and fertilizer application on nutritive value of durum wheat straw. J. Anim. Physiol. Anim. Nutr. 2007, 92, 121-130. [CrossRef]

54. Bezabeh, E.; Haregewoin, T.; Giorgis, D.H.; Daniel, F.; Belay, B. Change and growth rate analysis in area, yield and production of wheat in Ethiopia. Res. J. Agric. Environ. Manag. 2015, 4, 189-191.

55. Bassi, F.M.; Chiari, T.; Verma, R.P.S.; Kumar, S. Crop Diversification: The 'Old' Weapon in the Hands of Ethiopian Farmers, Borlaug Global Rust Initiative. Available online: http://www.globalrust. org/blog/crop-diversification- $\%$ E2\%80\%98old \%E2\%80\%99-weapon-hands-ethiopian-farmers (accessed on 10 January 2017).

56. Global Milling. Ethiopia Battles Wheat Rust Disease Outbreak in Critical Wheat-Growing Regions. Available online: http://globalmilling.com/ethiopia-battles-wheat-rust-disease-outbreak-in-critical-wheat-growingregions/ (accessed on 27 December 2016).

57. Tesemma, T.; Mohammed, J. Review of wheat breeding in Ethiopia. Ethiopian J. Agric. Sci. 1982, 1, 11-24.

58. Nastasi, V. Wheat Production in Ethiopia; Information Bulletin on the Near East Wheat and Barley Improvement and Production Project; FAO: Rome, Italy, 1964; Volume 1, pp. 13-24.

59. Tesemma, T. Durum wheat breeding in Ethiopia. In Fifth Regional Wheat Workshop for Eastern, Central and Southern Africa and the Indian Ocean; van Ginkel, M., Tanner, D.G., Eds.; CIMMYT: El Batan, Mexico, 1988; pp. 18-22.

60. Consultative Group on International Agricultural Research (CGIAR). Virulent new strains of Ug99 stem rust, a deadly wheat pathogen. Science Daily, 28 May 2010.

61. Ministry of Agriculture (MoA). Plant Variety Release, Protection and Seed Quality Control Directorate. Crop Var. Regist. 2013, 16, 301.

62. Leta, G.; Belay, G.; Walelign, W. Nitrogen fertilization effects on grain quality of durum wheat (Triticum turgidum L. var. durum) varieties in central Ethiopia. Agric. Sci. 2013, 4, 123-130.

63. Mekuria, T.; Wasihun, L.; Shitaye, H.; Asenafi, G. Durum wheat (Triticum durum Desf) Variety "Utuba" Performance in Ethiopia. Agric. Res. Technol. Open Access J. 2018, 18, 556063. [CrossRef] 
64. De Groote,H.; Gitonga, Z.; Mugo, S.; Walker, T.S. Assessing the effectiveness of maize and wheat improvement from the perspectives of varietal output adoption in east and southern Africa. In Crop Improvement, Adoption and Impact of Improved Varieties in Food Crops in Sub Saharan Africa; Walker, T.S., Alwang, J., Eds.; CABI: Egham, UK, 2015; pp. 207-227.

65. Dawit, A. Farmer-Based Seed Multiplication in the Ethiopian Seed System: Approaches, Priorities and Performance; FAC Working Paper 36; Future Agricultures Consortium: Brighton, UK, 2011.

66. Bishaw, Z. Wheat and Barley Seed Systems in Ethiopia and Syria. Ph.D. Thesis, Wageningen University, Wageningen, The Netherlands, 2004; pp. 1-401.

67. Joshi, A.K.; Azab, M.; Mosaad, M.; Braun, H.J. Delivering rust resistant wheat to farmers: A step towards increased food security. Euphytica 2011, 179, 187-196. [CrossRef]

68. Ojiewo, C.O.; Kugbei, S.; Bishaw, Z.; Rubyogo, J.C. Community seed production. FAO \& ICRISAT: 2015. In Workshop Proceedings, 9-11 December 2013; FAO: Rome, Italy; ICRISAT: Addis Ababa, Ethiopia, 2013; 176p.

69. Bishaw, Z.; Niane, A.A. Are farmer-based seed enterprises profitable and sustainable? Experiences of VBSEs from Afghanistan. In Proceedings of the Community Seed Production, Rome, Italy, 9-11 December 2013; FAO: Rome, Italy; ICRISAT: Addis Ababa, Ethiopia, 2013; pp. 55-64.

70. Board on Science and Technology for International Development (BOSTID). Lost Crops of Africa, Vol. I Grains; National Academic Press: Washington, DC, USA, 1996.

71. Central Statistical Agency (CSA). Agricultural Sample Survey 2013/2014, Statistical Bulletin No 536; Federal Democratic Republic of Ethiopia Central Statistical Agency: Addis Ababa, Ethiopia, 2014; pp. 1-121.

72. D'Andrea, C.A.; Haile, M. Traditional emmer processing in highland Ethiopia. J. Ethnobiol. 2002, 22, $179-217$.

73. Cooper, R. Re-discovering ancient wheat varieties as functional foods. J. Tradit. Complement. Med. 2015, 5, 138-143. [CrossRef] [PubMed]

74. Stallknecht, G.F.; Gilbertson, K.M.; Romey, J.E. Alternative wheat cereals as good grains: Einkorn, emmer, spelt, kamut and triticale. In Progress in New Crops; Janick, J., Ed.; ASHS Press: Alexandria, VA, USA, 1997; pp. 156-170.

75. Negassa, M. Possible new genes for resistance to powdery mildew, septoria glume blotch and leaf rust of wheat. Plant Breed. 1987, 98, 37-46. [CrossRef]

76. Damania, A.B.; Hakim, S.; Moualla, M.Y. Evaluation of variation in T. dicoccum for wheat improvement in stress environment. Hereditas 1992, 116, 163-166. [CrossRef]

77. Robinson, J.; Skovmand, B. Evaluation of emmer wheat and other Triticeae for resistance to Russian wheat aphid. Genet. Resour. Crop Evol. 1992, 39, 159-163.

78. Naod, B.; Fininsa, C.; Badebo, A. Sources of stem rust resistance in Ethiopian tetraploid wheat accessions. Afr. Crop Sci. J. 2007, 15, 51-57.

79. Oliver, R.E.; Cai, X.; Friesen, T.L.; Halley, S.; Stack, R.W.; Xu, S.S. Evaluation of Fusarium head blight resistance in tetraploid wheat (Triticum turgidum L.). Crop Sci. 2008, 48, 213-222. [CrossRef]

80. Ethiopian Revenues and Customs Authority (ERCA). 2014. Available online: http://www.erca.gov.et/index. php (accessed on 5 January 2017).

81. Geleto, T.; Tanner, D.G.; Mamo, T.; Gebeyehu, G. Response of rainfed bread and durum wheat to source, level and timing of nitrogen fertilizer on two Ethiopian vertisols: N uptake, recovery and efficiency. Fertil. Res. 1996, 44, 195-204. [CrossRef]

82. Biggeri, M.; Ciani, F.; Ferrannini, A. Aid effectiveness and multilevel governance: The case of a value chain development project in rural Ethiopia. Eur. J. Dev. Res. 2016, 29, 843-865. [CrossRef]

83. Ministry of Agriculture (MOA). Plant Variety Release, Protection and Seed Quality Control Directorate. Crop Var. Regist. 2015, 17, 330.

84. Biggeri, M.; Burchi, F.; Ciani, F.; Herrmann, R. Linking small-scale farmers to the durum value chain in Ethiopia: Assessing the effects on production and wellbeing. Food Policy 2018, 79, 77-91. [CrossRef]

85. Falaki, A.M.; Mohammed, I.B. Performance of some durum wheat varieties at Kadawa, Kano state of Nigeria. Bayero J. Pure Appl. Sci. 2011, 4, 48-51. [CrossRef]

86. Agriculture in Mauritania. Encyclopedia of the Nations-Information about Countries of the World, United Nations and World Leaders. Available online: http://www.nationsencyclopedia.com/Africa/MauritaniaAGRICULTURE.html (accessed on 15 December 2016). 
87. Sall, A.T.; Kabbaj, H.; Cisse, M.; Gueye, H.; Ndoye, I.; Maltouf, A.F.; El-Mourid, M.; Ortiz, R.; Bassi, F.M. Heat Tolerance of Durum Wheat (Tritcum durum Desf.) Elite Germplasm Tested along the Senegal River. J. Agric. Sci. 2018, 10, 217-233. [CrossRef]

88. Food and Agriculture Organization (FAO). Senegal: Irrigation Market Brief; Report No. 26; FAO: Rome, Italy, January 2016.

89. Manikowski, S.; Strapasson, A. Sustainability Assessment of Large Irrigation Dams in Senegal: A Cost-Benefit Analysis for the Senegal River Valley. Front. Environ. Sci. 2016, 4, 18. [CrossRef]

90. Mahajan, A.; Gupta, R.D. Integrated Nutrient Management (INM) in a Sustainable Rice-Wheat Cropping System; Springer: Heidelberg, Germany, 2009; p. 268.

91. Club du Sahel (CILSS). Development of Irrigated Agriculture in Upper Volta: Proposals for a Second Programme 1980-85; Permanent Interstate Committee for Drought Control in the Sahel: Niamey, Republic of Niger, 1979.

92. Chabrolin, R. Programme pour les Recherches Concernant le blé au Mali; Fonds IRD: B22431. 1967.

93. USDA Foreign Agricultural Service. 2018 Grain and Feed Annual Nigeria-USDA GAIN Reports. Available online: https://gain.fas.usda.gov/Recent\%20GAIN\%20Publications/Grain\%20and\%20Feed\%20Annual_ Lagos_Nigeria_4-12-2018.pdf (accessed on 5 March 2019).

94. Stansbury, C.D.; Pretorius, Z.A. Modelling the potential distribution of Karnal bunt of wheat in South Africa. S. Afr. J. Plant Soil 2001, 18, 159-168. [CrossRef]

95. Singh, R.P.; Hodson, D.P.; Huerta-Espino, J.; Jin, Y.; Bhavani, S.; Njau, P.; Herrera-Foessel, S.; Singh, P.K.; Singh, S.; Govindan, V. The emergence of Ug99 races of the stem rust fungus is a threat to World wheat production. Annu. Rev. Phytopathol. 2011, 49, 465-481. [CrossRef]

96. Duveiller, E.; Mezzalama, M. Karnal Bunt: Screening for Resistance and Distributing KB Free Seed; CIMMYT: El Batan, Mexico, 2009.

97. Letta, T.; Olivera, P.; Maccaferri, M.; Jin, Y.; Ammar, K.; Badebo, A.; Noli, E.; Crossa, J.; Tuberosa, R. Genome-wide search of stem rust resistance loci at the seedling stage in durum wheat. Plant Genome 2014, 7, 1-13. [CrossRef]

98. Ravelomamtsoa, S.H.; Randrianaivoarivony, J.M.; Ramalanjaona, V.L. Overview of wheat in Madagascar. In Proceedings of the Wheat for Food Security in Africa, Addis-Ababa, Ethiopia, 8-12 October 2012.

99. Rajaram, S.; van Ginkel, M.; Fischer, R.A. CIMMYT's wheat breeding mega-environments (ME). In Proceedings of the 8th International Wheat Genetics Symposium, Beijing, China, 19-24 July 1994.

100. Zaharieva, M.; Bonjean, A.; Monneveux, P. Alert: Saharan Oases wheat genetic resources in danger. In World Wheat Book: A History of Wheat Breeding; Bonjean, A.P., Angus, W.J., van Ginkel, M., Eds.; Lavoisier: Paris, France, 2016; Volume 3, pp. 543-588.

101. Saharan Development. Agriculture and Farming. Available online: http://www.sahara-developpement.com/ Western-Sahara/AgricultureEtElevage--117.aspx (accessed on 26 December 2016).

102. Food and Agriculture Organization (FAO). La Mauritanie et la FAO: Partenariat pour Améliorer la Résilience et Renforcer la Sécurité Alimentaire et Nutritionnelle. Available online: http://www.fao.org/3/a-au199f.pdf (accessed on 25 December 2016).

103. Food and Agriculture Organization (FAO)-ISESCO. In Proceedings of the International Workshop on Globally Important Agriculture Heritage Systems (GIAHS) for the Islamic Countries, Rome, Italy, 4-5 November 2014.

104. Houichiti, R.; Bissati, S.; Bouammar, B. Oasis agriculture and food insecurity in Algeria: The case of Ghardaia region. Pensee J. 2014, 76, 1-7.

105. Ait, H. Systemes de production et stratégies des agriculteurs dans les oasis de la region d'Errachidia au Maroc. New Medit. 2003, 2, 37-43.

106. El Abbass, S. Systèmes d'irrigation dans les oasis de Mauritanie: Problèmes de pompage et tentatives de réalimentation des nappes phréatiques. In Proceedings of the Journées Internationales sur l'Agriculture et la Gastronomie des Oasis, Elche, Spain, 14-15 October 2009.

107. Merouche, A.; Debaeke, P.; Messahel, M.; Kelkouli, M. Response of Durum wheat varieties to water in semi-arid Algeria. Af. J. Agric. Res. 2014, 9, 2880-2893.

108. Zaharieva, M.; Bonjean, A.; Monneveux, P. Saharan wheats: Before they disappear. Genet. Resour. Crop Evol. 2014, 61, 1065-1084. [CrossRef]

109. Benlaghlid, M.; Bouattoura, N.; Monneveux, P.; Borries, C. Etude de la diversité génétique et de la physiologie de l'adaptation au milieu. Options Méditerranéennes 1990, 11, 171-194. 
110. Constantinidou, K.; Zittis, G.; Hadjinicolaou, P. Variations in the Simulation of Climate Change Impact Indices due to Different Land Surface Schemes over the Mediterranean, Middle East and Northern Africa. Atmosphere 2019, 10, 26. [CrossRef]

111. South African Revenue Service. Available online: www.sagis.org.za/sars.html (accessed on 7 February 2017).

112. William, A.R. Market Trends Category Analysis: A Look into the Pasta. Available online: www.preparedfoods. com/articles/103693-market-trends-category-analysis-a-look-into-the-pasta (accessed on 5 January 2017).

113. Karaimu, P. Africa Research in Sustainable Intensification for the Next Generation. Available online: https://africa-rising.net/ (accessed on 15 May 2019).

114. Hauser, J.F. Support to Agricultural Research for Development of Strategic Crops in Africa. Available online: http://sard-sc.org/ (accessed on 15 May 2019).

115. IITA. TAAT Launch Signifies New Day for African Agriculture. Available online: https://www.iita.org/newsitem/taat-launch-signifies-new-day-african-agriculture/ (accessed on 15 May 2019).

(C) 2019 by the authors. Licensee MDPI, Basel, Switzerland. This article is an open access article distributed under the terms and conditions of the Creative Commons Attribution (CC BY) license (http://creativecommons.org/licenses/by/4.0/). 